\title{
レポート REPORT
}

\section{宮城県仙台市におけるハヤブサの人工巣利用事例： センサーカメラによる有効性の検証}

\section{海原 $\quad$ 要 ${ }^{1 *} \cdot$ 野口 $\quad$ 泰司 $^{1{ }^{1}} \cdot$ 清水 $\quad$ 信一 ${ }^{2)} \cdot$ 由井 正敏 ${ }^{3}$}

1）東北緑化環境保全株式会社％980-0014 宮城県仙台市青葉区本町 2-5-1

2）東北電力株式会社％980-8550 宮城県仙台市青葉区本町 1-7-1

3）東北鳥類研究所 $\bar{T} 020-0611$ 岩手県滝沢市巣子 152-137

\section{Kaname KAIHARA $^{1) *}$, Yasushi NOGUCHI ${ }^{1)}$, Shinichi SHIMIZU ${ }^{2)}$, Masatoshi YUI $^{3)}$ : Falcon, Falco peregrinus artificial nest use case in Sendai City, Miyagi Prefecture: Verification of effectiveness with sensor camera. Ecol. Civil Eng.}

1) Tohoku Greening \& Environmental Consulting Co., Ltd., 2-5-1, Honcho, Aoba-ku, Sendai, Miyagi, 980-0014, Japan

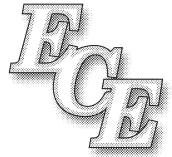

Ecology and Civil Engineering

2) Tohoku Electric Power Co., Inc., 1-7-1 Honcho, Aoba-ku, Sendai, Miyagi, 9808550, Japan

3) Tohoku Ornithological Research Institute, 152-137, Sugo, Takizawa, Iwate, 0200611, Japan

\section{はじめに}

ハヤブサ（Falco peregrinus 英名 Falcon）はハヤブサ 科の小型猛禽類で, 日本では北海道から九州まで広く分 布しており, 宮城県では留鳥として繁殖している。 八ヤ ブサは自分では巣を造らず，人が容易に近寄れない断崖 の垂直の壁の途中にある岩棚や岩穴を巣として使用する ことが多い，人工物に巣を構えることも多く，高層ビル， 鉄塔, 橋脚等, 条件さえ合えば様々な場所で営巣する (森岡ほか 1998).

ハヤブサは希少な猛禽類として種の保存法で国内希少 野生動植物種（1993 年指定）, 環境省レッドリスト等で 絶滅危惧 II 類（環境省 2006, 2014, 2020）に指定されて いるほか, 全都道府県で各種指定されており, 宮城県で もレッドリスト等（宮城県 2001, 2016, 2021）で準絶滅 危惧に指定されている.

今回報告する宮城県仙台市の新仙台火力発電所のリプ レース事業（2007～2019 年）に際して実施した環境影

2021 年 5 月 23 日受付, 2021 年 8 月 12 日受理

早期公開 (J-STAGE)

J-STAGE Advance published

doi: https://doi.org/10.3825/ece.21-00013

*e-mail: kaihara-k@tohoku-aep.co.jp
響評価法に基づく環境調査では，撤去予定の旧煙突でハ ヤブサの営巣が確認されたため, ハヤブサに対する環境 保全措置として新たに建設する煙突に人工巣（金属製巣 箱）を設置するものとした。

猛禽類に対する人工代替巣を用いた保全事例について は, 長谷川ほか（2016）に猛禽類 8 種の 31 事業 173 事 例がまとめられているが, 分析対象を道路事業に限定し ていたため, 主に崖地を繁殖地とするハヤブサについて は 2 事業 7 事例, うち繁殖成功は 1 事業 1 事例と少なか った. 成功した事業は兵庫県姫路市の一般国道 29 号姫 路北バイパス事業（上野ほか 2016）で, 崖地の一部を 代替巣として利用できるように整備した結果, 繁殖成功 が確認されている。残り1つは新潟県岩船郡関川村の一 般国道 113 号鷹ノ巣道路事業（㝨輪ほか 2017）で, こち らは人工巣 (金属製巣箱) を鉄塔に設置したものの, 八 ヤブサの利用は確認されていない。 その他の人工巣（金 属製巣箱）の設置例として, 山口県山陽小野田市の中国 電力新小野田発電所 (中国電力ホームページ・新小野田 発電所の概要 https://www.energia.co.jp/area/yamaguchi/ entry/324.html, 2021 年 4 月 1 日確認), 北海道広尾町 の一般国道 336 号黄金道路事業（西山ほか 2013）があ り，そのうち中国電力新小野田発電所では地上 $50 \mathrm{~m}$ の 
煙突に設置された人工巣で繁殖成功が確認されている.

ハヤブサを含めた猛禽類は繁殖期に警戒度が極大とな

り，その時期に長期間連続的に人が直接観察することは 繁殖を擋乱するおそれがあるため, 繁殖巣付近にカメラ を設置して映像監視する調査方法が実施されている。八 ヤブサにおけるカメラを使用した観察事例として，佐賀 県唐津市の一般国道2 03 号㛜木バイパス（上野ほか 2016 ; 佐賀国道事務所ホームページ・㛜木バイパスハヤ ブサコーナー http://www.qsr.mlit.go.jp/sakoku/activity/ hayabusa/index.html, 2021 年 4 月 1 日確認)，大阪府泉大 津市のホテルサンルート関空（泉大津ハヤブサ・サポー 卜俱楽部ホームページ http://www.ne.jp/asahi/hayabusa/ izumiotsu/, 2021 年 4 月 1 日確認) がある。厳木バイパ スは, ハヤブサ営巣地より約 $300 \mathrm{~m}$ 離れた場所に観測 小屋を建て，高倍率ビデオカメラと広角ビデオカメラを 用いて観察している。 ホテルサンルート関空では, ベラ ンダでハヤブサが営巣したことから，営巣場所を見下ろ せる位置にビデオカメラを設置して観察している。これ らは映像を 24 時間ハードディスクに録画することで詳 細な生態観察を可能としているものの，撮影システムの 構築に費用がかかってしまう。比較的安価な撮影方法と しては，市販のセンサーカメラ（自動撮影カメラ）を用 いた方法があり，国内では北海道でオオタカAccipiter gentilis, ハイタカ Accipiter nisus, オジロワシ Haliaeetus albicilla, クマタカ Nisaetus nipalensis, ノスリButeo buteo 及びトビ Milvus migrans の営巣地で実施した事例 （嘉藤ほか 2021）があるが，ハヤブサで実施した事例は 報告されていない.

本報告では，建設事業の環境保全措置としてハヤブサ
の人工巣を設置し, 実際に利用が見られたため, その詳 細を報告する。合わせて, 人工巣の利用を促す工夫や留 意点, 並びに利用状況をセンサーカメラでモニタリング した観察結果について報告する。

\section{材料と方法}

\section{1) 調査地}

ハヤブサ営巣地は宮城県仙台市の東北電力株式会社新 仙台火力発電所に位置している。営巣地の東側及び南側 は仙台塩釜港に面しており，西側及び北側は工業地帯と なっている。

\section{2) 人工巣}

人工巣の構造は, 成功事例のある中国電力新小野田発 電所の人工巣を参考にした。材質は厚さ $1 \mathrm{~mm}$ のステン レス製。巣本体は横幅 $80 \mathrm{~cm} \times$ 奥行 $55 \mathrm{~cm} \times$ 高さ $50 \mathrm{~cm}$ (前方は $40 \mathrm{~cm}$ ), 屋根は横幅 $80 \mathrm{~cm} \times$ 奥行 $66 \mathrm{~cm}$ ，入口 が横幅 $45 \mathrm{~cm} \times$ 縦幅 $35 \mathrm{~cm}$ で，両側面と後面には換気穴 （直径約 $1.5 \mathrm{~cm}$ ）を付けた。また，巣内部の床には小石 とモルタルを混ぜたものを厚さ $5 \mathrm{~cm}$ 程度敷いた。止ま り場は入口から $30 \mathrm{~cm}$ の距離に直径約 $3 \mathrm{~cm}$ のパイプを 設置した（図 1 ）。

人工巣は 2015 年 10 月に，旧煙突で繁殖した営巣場所 の高さ $(76 \mathrm{~m})$ を参考にして，新たに建設した 2 基の 煙突（3-1 号及び 3-2 号煙突）の 4 段目（76 m) にそれ ぞれ 1 個ずつ（合計 2 個）設置した．3-1 号及び 3-2 号 煙突には東側に点検作業時等に使用する階段が設置され ており，3-1 号煙突では階段付近の北東側の柱の陰に, 3-2 号煙突では階段から離れた北西側の柱の陰にそれぞ

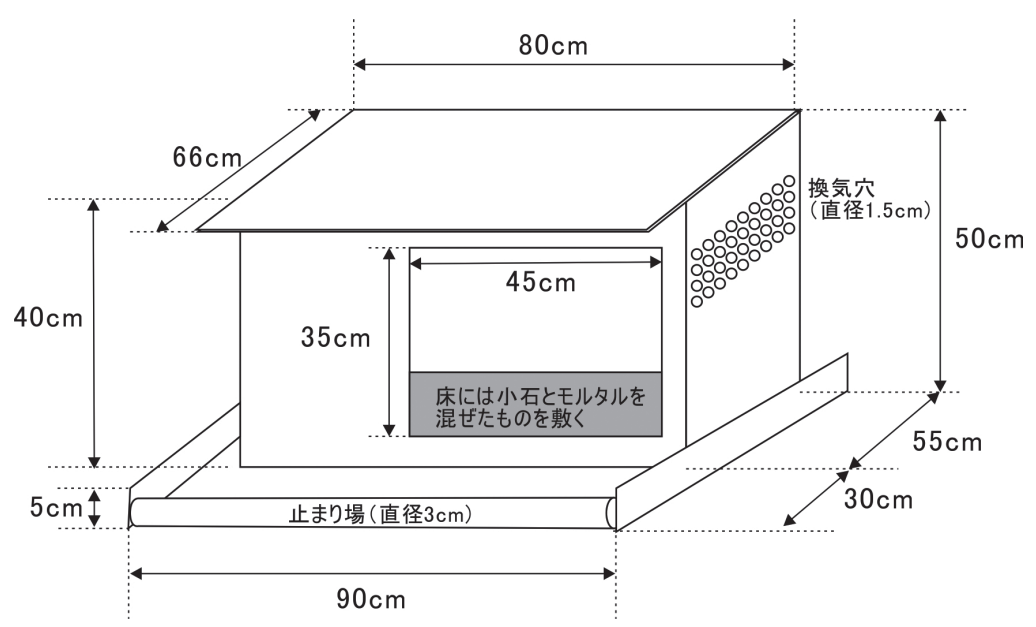

図 1. 人工巣の構造. 
れ設置した (図 2). 入口の向きは 3-1 号煙突が南西向き, 3-2 号煙突が南東向きである.

3) センサーカメラ

センサーカメラはこれまで 3 機種を使用している（表

1). Ltl Acorn 5210B は赤外線検知式で, 単三形乾電池 8

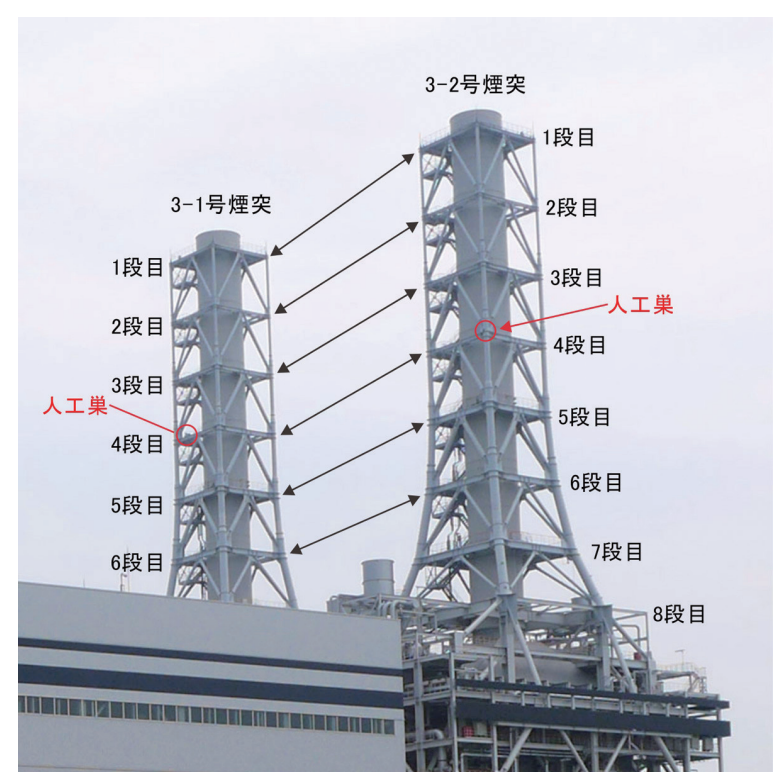

図 2. 人工巣設置位置.
本を電源とし，1 度の検知で静止画を 3 枚撮影, インタ ーバル 1 分後に待機状態に戻る設定とした.

HykeCam SP4G 及び LT4G には，撮影した静止画を電 子メールでインターネットサーバー上にアップロードす る通信機能が付加されているが, その分消費電力が多く なるため, 煙突から供給される直流 $6 \mathrm{~V}$ を外部電源とし て，静止画及び動画を撮影した。 1 度の検知で静止画 1 枚及び動画 30 秒撮影, インターバル 1 分後に待機状態 に戻る設定とした。

センサーカメラは, 各煙突東側の階段手すりに設置し た（図 3). センサーカメラから人工巣までの距離は, 3-1 号煙突では約 $1.5 \mathrm{~m}, 3-2$ 号煙突では約 $6 \mathrm{~m}$ であった。 記録媒体は SD カード（16３2 GB）を使用したが, 容 量に限界があるため 1 ～2 かこことに交換した

\section{結果と考察}

\section{1）リプレース工事期間とハヤブサ繁殖状況}

ハヤブサの繁殖は 2007 年に旧煙突で初確認された (表 2). 2012 年から発電所のリプレース工事が開始され たが，2012２013 年は変わらず旧煙突で繁殖した。旧 煙突では, 繁殖成功は 2007 年と 2012 年の 2 回のみであ った。なお， 2011 年は繁殖開始時期に東日本大震災が

表 1. 使用したセンサーカメラの機種.

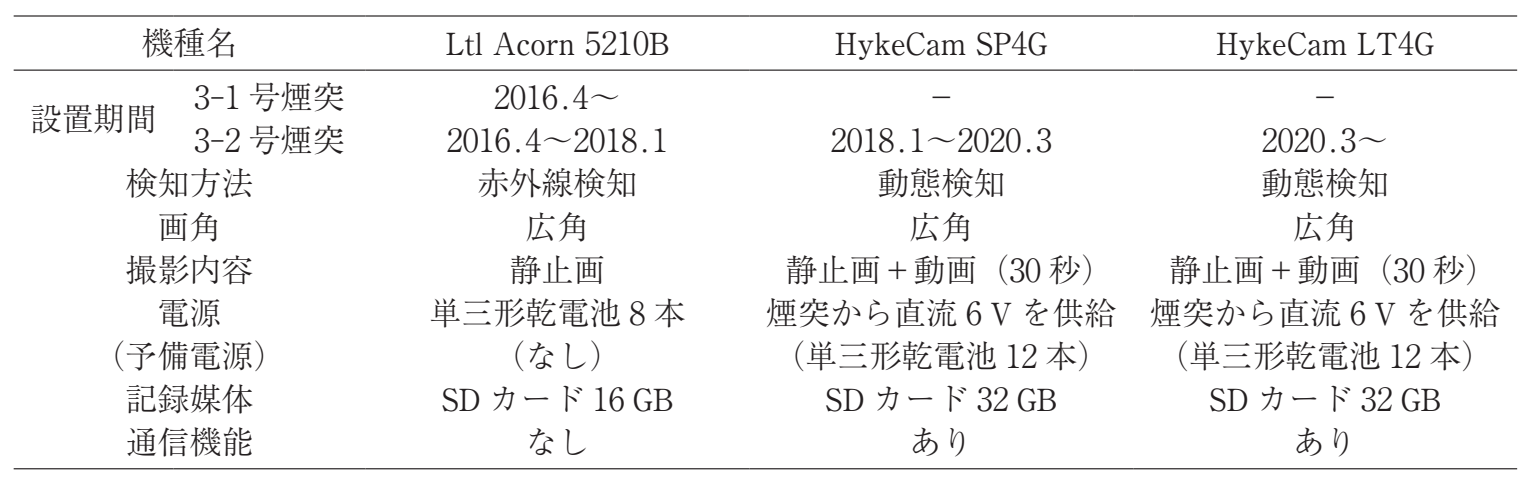

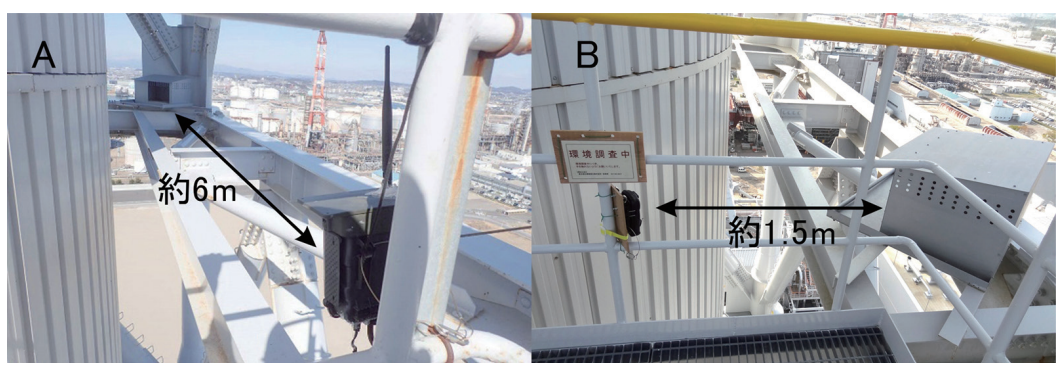

図 3. センサーカメラ設置位置. A : 3-2 号煙突, B : 3-1 号煙突. 
表 2.リプレース工事期間とハヤブサ繁殖状況.

\begin{tabular}{|c|c|c|c|c|c|c|}
\hline \multirow{3}{*}{ 年 } & \multicolumn{2}{|c|}{ リプレース工事期間 } & \multicolumn{4}{|c|}{ 各営巣地のハヤブサ繁殖状況 } \\
\hline & \multirow{2}{*}{$\begin{array}{c}\text { 旧施設 } \\
\text { 撤去工事 }\end{array}$} & \multirow{2}{*}{$\begin{array}{c}\text { 新施設 } \\
\text { 設置工事 }\end{array}$} & \multirow{2}{*}{ 旧煙突 } & \multirow{2}{*}{ 岩場* } & \multicolumn{2}{|c|}{ 人工巣 } \\
\hline & & & & & 3-1 号煙突 & 3-2 号煙突 \\
\hline 2007 & & & 0 & & & \\
\hline 2008 & & & $\Delta$ & & & \\
\hline 2009 & & & $\Delta$ & & & \\
\hline 2010 & & & $\Delta$ & & & \\
\hline 2011 & & & $\times$ & & & \\
\hline 2012 & & $\bigcirc$ & O & & & \\
\hline 2013 & $\bigcirc$ & $\bigcirc$ & $\Delta$ & & & \\
\hline 2014 & 0 & $\bigcirc$ & - & 0 & & \\
\hline 2015 & $\bigcirc$ & $\bigcirc$ & - & 0 & 10 月設置 & 10 月設置 \\
\hline 2016 & $\bigcirc$ & $\bigcirc$ & - & 0 & - & - \\
\hline 2017 & $\bigcirc$ & $\bigcirc$ & 9 月撤去開始 & - & - & 0 \\
\hline 2018 & $\bigcirc$ & & 3 月撤去終了 & - & - & $\boldsymbol{\Delta}$ \\
\hline 2019 & $\bigcirc$ & & & - & - & - \\
\hline 2020 & & & & - & - & 0 \\
\hline 2021 & & & & - & - & 0 \\
\hline
\end{tabular}

: 繁殖成功, $\boldsymbol{\Delta}$ : 繁殖途中失敗, $\times$ : 繁殖失敗, 一 : 繁殖を実施せず, $\bigcirc$ : 工事を実施 *発電所から東方向に約 $1.5 \mathrm{~km}$ 離れた場所に位置する岩場。2007〜2013 年は未確認.

発生した影響で繁殖失敗となった。

2014 年になると発電所から東へ約 $1.5 \mathrm{~km}$ 離れた岩場 に営巣地を移動したが, 繁殖終了後は発電所を中心に行 動していたほか，狩り行動は年間を通じて発電所周辺で 確認されていたことから，工事が本格化した影響で営巣 地のみを移動させたと考えられる。この岩場では 2016 年まで 3 回連続で繁殖成功している.

人工巣は 2015 年 10 月に設置されたが, 2016 年 8 月 までハヤブサが撮影されなかったことから，2016 年の 繁殖期にはまだ人工巣がハヤブサに認識されていなかっ たと考えられる。2016 年 8 月以降は人工巣を利用する ようになり，2017 年は旧煙突，岩場，人工巣と全ての 営巣可能な場所が揃っていたが，その中で 3-2 号煙突人 工巣が選択され，2羽が巣立った。

2018 年も同様に $3-2$ 号煙突人工巣で繁殖開始したも のの，5月 9 日を最後に親成鳥が確認されなくなり，残 された雛は衰弱して死亡した。その後は 2019 年 5 月ま で発電所周辺をなわばりとするハヤブサが不在状態とな ったが，2019年 6 月から新たな成鳥ペアが確認される ようになり，2020 年は 3-2 号煙突人工巣から 3 羽が, 2021 年は 3-2 号煙突人工巣から 2 羽が巣立った。

\section{2） 2 つの人工巣の比較}

ハヤブサは 3-1 号煙突でも撮影されており，人工巣に
入る行動も確認されているが，これまでの人工巣での繁 殖は全て 3-2 号煙突人工巣で実施されている。この $2 つ$ の人工巣は構造及び設置高さは同様であるが, 設置位置 が異なっている．3-1 号煙突では煙突東側の階段からす ぐ近くに設置されているのに対して，3-2 号煙突では階 段から約 $6 \mathrm{~m}$ 離れた反対側の柱に設置されている(図 3). そのため, 八ヤブサが繁殖場所を選択する際に，人の立 ち入り可能な場所からの距離がより遠い 3-2 号煙突人工 巣を選択している可能性が考えられる。

\section{3）センサーカメラによって得られた情報}

今回ハヤブサが繁殖した $3-2$ 号煙突人工巣では， 3 月 10 日頃に産卵，4 月中旬に梛化した雛，5月下旬に幼鳥 の巣立ちが確認された（表 3)。センサーカメラによっ て得られた情報として，人工巣への渡来日（時刻），交 尾, 成鳥による巣内育雛行動（抱卵, 抱雛, 給餌), 餌 の搬入 (回数, 時間), 卵数, 雛数, 巣立ち日等が挙げ られる（図 4)。一方，人工巣から約 $6 \mathrm{~m}$ 離れた場所か らの広角撮影で人工巣内部に撮影死角が存在したため, 卵が確認できない場合もあったほか，運ばれた飭の判別， 産卵の開始日や間隔，孵化日等の把握は困難であった。 これらを把握するためには，人工巣そのものにカメラを 設置する等の人工巣内部を詳細に撮影可能な方法が必要 と考えられるが，繁殖成功の確認を目的とする場合には， 
表 3. 人工巣でのハヤブサ繁殖状況：センサーカメラによる確認日及び確認数.

\begin{tabular}{|c|c|c|c|c|c|}
\hline & 項目 & 2017 年 & 2018 年 & 2020 年 & 2021 年 \\
\hline 確認日 & $\begin{array}{c}\text { 抱卵姿勢 } \\
\text { 卵 } \\
\text { 雛 } \\
\text { 巣立ち }\end{array}$ & $\begin{array}{c}3 \text { 月 } 9 \text { 日 } \\
\text { 確認できず* } \\
4 \text { 月 } 20 \text { 日 } \\
5 \text { 月 } 24 \text { 日 }\end{array}$ & $\begin{array}{c}3 \text { 月 } 6 \text { 日 } \\
3 \text { 月 } 11 \text { 日 } \\
4 \text { 月 } 22 \text { 日 } \\
-\end{array}$ & $\begin{array}{c}3 \text { 月 } 12 \text { 日 } \\
3 \text { 月 } 11 \text { 日 } \\
4 \text { 月 } 21 \text { 日 } \\
5 \text { 月 } 27 \sim 31 \text { 日 }\end{array}$ & $\begin{array}{c}3 \text { 月 } 12 \text { 日 } \\
3 \text { 月 } 11 \text { 日 } \\
4 \text { 月 } 15 \text { 日 } \\
5 \text { 月 } 27 \sim 28 \text { 日 }\end{array}$ \\
\hline 確認数 & $\begin{array}{c}\text { 産卵数 } \\
\text { 梛孚化数 } \\
\text { 巣立った幼鳥数 }\end{array}$ & $\begin{array}{c}\text { 不明* } \\
2 \\
2\end{array}$ & $\begin{array}{l}2 \\
1 \\
-\end{array}$ & $\begin{array}{l}3 \\
3 \\
3\end{array}$ & $\begin{array}{l}3 \\
2 \\
2\end{array}$ \\
\hline
\end{tabular}

※センサーカメラからは死角となっていたため, 確認できなかった.

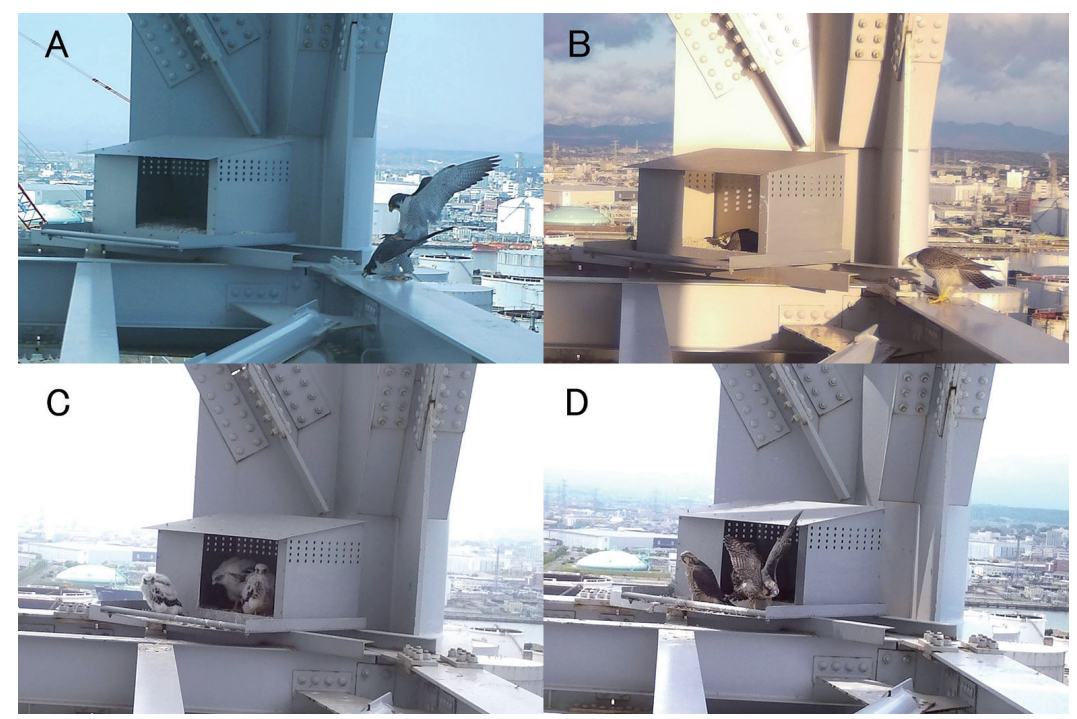

図 4. センサーカメラで撮影されたハヤブサ. A : 交尾 (2017 年 3 月 5 日 撮影), B : 抱卵中の成鳥 (2020 年 3 月 12 日撮影), C : 雛 3 羽 (2020 年 5 月 16 日撮影)，D：巣立ち間近の幼鳥 (2020 年 5 月 26 日撮影).

センサーカメラで十分把握可能であると考えられる.

ハヤブサ以外の鳥類として，ハシブトガラス Corvus macrorhynchos, イソヒヨドリ Monticola solitarius 及びド バトColumba liviaが撮影された。 そのうち，ハシブト ガラスは 2018 年の繁殖失敗時に雛を襲いに来ている姿 が撮影された。 2019 年にも 4 月に人工巣内部へ入る姿 が撮影されており，人工巣を飭がある場所と認識してい る可能性が考えられる。 なお， 2020 年及び 2021 年の繁 殖時には撮影されておらず，親成鳥による警戒のため近 寄れなかったと考えられる。

カメラのセンサーは，ハヤブサ以外にも反応した事例 が認められた. Ltl Acorn 5210B は赤外線検知式のため, 発電所から発生する水蒸気の煙に反応して作動した事例 があった. HykeCam SP4G 及び LT4G は動態検知のため, 強風によってカメラ本体が摇らされて作動した事例, 濃
い煙を検知して作動した事例があった。一方で，ハヤブ サの行動が速すぎて検知から撮影までの夕イムラグに撮 影範囲外へ移動してしまい, 写らなかったと考えられる 事例もあった。

HykeCam SP4G 及び LT4G の通信機能は, 携帯電話回 線を利用して送信するため, 携带電波圈外では使用でき ないという欠点はあるものの, 繁殖状況をほぼリアル夕 イムで確認可能となるため, 非常に有用な機能であった。 なお，地震の影響で外部電源が外れてしまい，予備電源 の乾電池のみとなった際, 乾電池の残量が半分程度の段 階では検知及び撮影は継続されていたものの通信が困難 となったため，安定して通信するためには外部電源を用 いることが望ましいと考えられる。

\section{4) 餌運び}

2020 年 2～ 5 月に 3-2 号煙突人工巣では 1 日あたり 0 


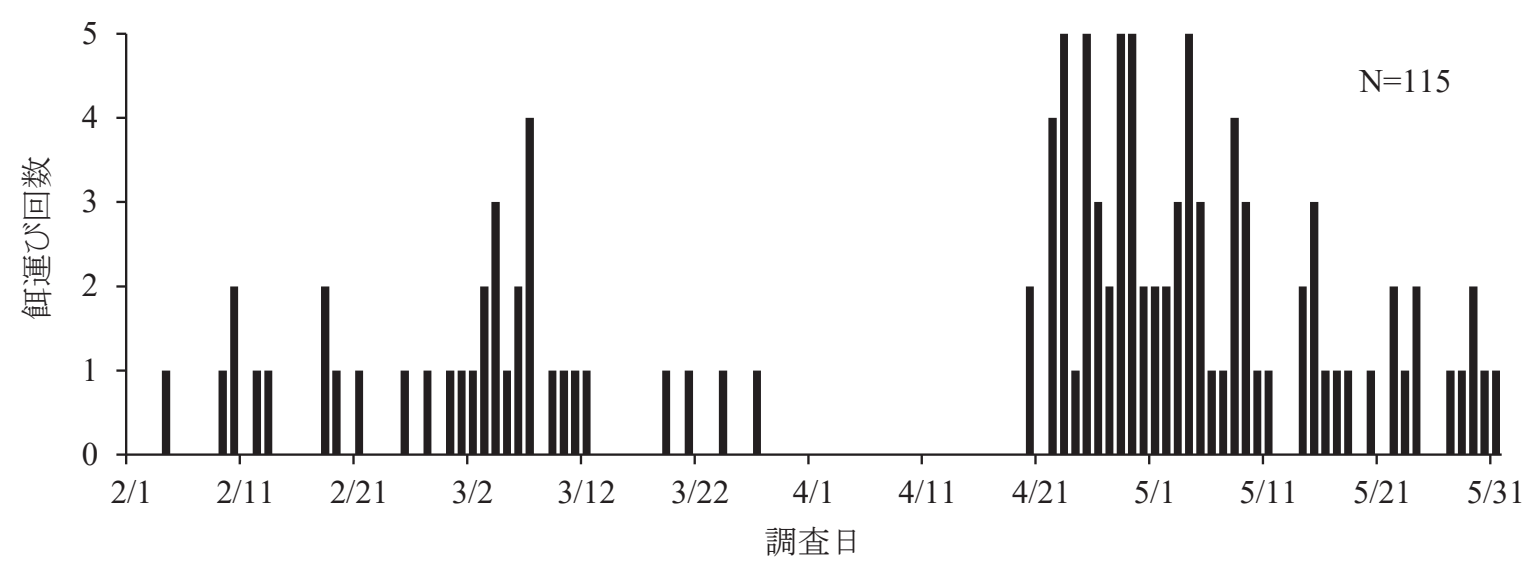

図 5. 日別餌運び回数の推移（2020 年 2 月 1 日〜 5 月 31 日）.

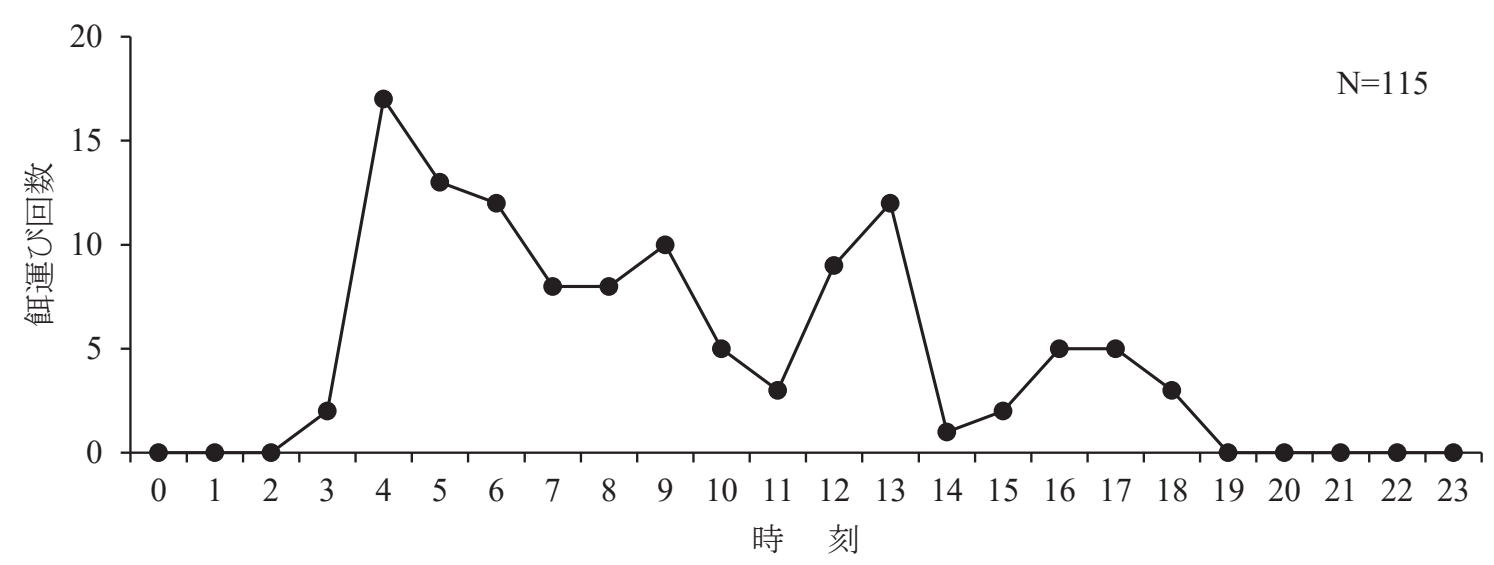

図 6. 時刻別餌運び回数の推移（2020 年 2 月 1 日 5 月 31 日）.

〜 5 回, 期間合計 115 回の餌運びが確認された（図 5). 2 月の餌運びは, 雄成鳥から雌成鳥に対する求愛給餌と 考えられる。3月上旬は産卵時期にあたるため，栄養を 欲した雌成鳥に対して何度も慨を運んだ可能性が考えら れる。 3 月 12 日以降の抱卵期間は回数が最も少なくな つたが，抱卵交代しながら雌雄各自で飭を確保していた 可能性が考えられる。雛が孵化した 4 月 20 日以降は急 激に成長する雛 3 羽分の餌を賄うために回数が増加した と考えられる。

時刻別では午前 4 時台が最も多く, 次いで 5 時台と夜 明け前〜直後にあたる早朝に餌運びされる傾向がみられ た（図 6)。この時間带は，餌動物である小鳥類の移動 が活発になり見つけやすい, 外敵に対する警戒がおろそ かになる等の何らかの理由があるものと考えられる.

餌運びでは，雄成鳥が人工巣へ運んできた慨を雌成鳥 が奪おうとするも，雄成鳥がそれを嫌がって飭を持って 飛び去り，雌成鳥が追っていくという行動も確認された.
センサーカメラは広角撮影のため飭動物の種判別は困 難であったが，3-1 号及び 3-2 号煙突にはハヤブサが狩 ったと思われる鳥の死骸が残されている場合があり，こ れまでにウズラ Coturnix japonica (11月発見)，コガモ Anas crecca (2月), ドバト (2月・3 月・ 11 月), クイ ナRallus aquaticus (11月), カモメ類の雛（6月），チョ ウゲンボウ Falco tinnunculus (11 月), モズ Lanius Bucephalus（11月）及びヒバリAlauda arvensis（7月） の 8 種が確認されている.

\section{5）警戒行動}

人工巣は現在稼働中の発電所煙突に設置されているた め, 繁殖期間中でも定期点検等で人工巣付近に人が立ち 入る場合がある。その際, 成鳥が煙突の周囲を鳴きなが ら飛翔するという警戒行動がみられたが, 作業員が煙突 を降りるに伴い, 警戒行動を終了していた，人に対して の攻撃行動は確認されていない.

なお， 2018 年の繁殖失敗時について，成鳥が最後に 
確認された 5 月 9 日から遡って 1 か月の間に人工巣付近 への人の立ち入りが無いこと, 2017 年は同じ場所で繁 殖成功していることから，人為的影響で繁殖放裹した可 能性は低いと考えられる.

3-1 号煙突ではセンサーカメラから人工巣までの距離 が約 $1.5 \mathrm{~m}$ とかなり近いが, 八ヤブサがセンサーカメラ を注視するような警戒行動はこれまで確認されていない. センサーカメラの目の前で羽づくろいを 30 分以上続け た事もあり，基本的にセンサーカメラを気にしていない と考えられる. 他の猛禽類では巣付近に設置されたセン サーカメラに反応したり注視したりする事例が紹介され ているが（嘉藤ほか 2021）, これらは自然環境にセンサ 一カメラという人工物を設置したため違和感が生まれた 可能性が考えられる. しかし, 本事例は元々人工建築物 に設置しているため違和感が少ないこと，ハヤブサが人 工巣を認識した際には既にセンサーカメラを設置済みで あったことから，違和感無く受け入れられた可能性が考 えられる。

\section{6) 人工巣の効果とセンサーカメラによる調査}

リプレース工事によりハヤブサは営巣地を一時的に発 電所敷地外へ移したものの, 人工巣設置後は発電所で再 び繁殖したことにより，人工巣設置がハヤブサの保全措 置として有効であったと考えられる。中国電力新小野田 発電所では人工巣で繁殖成功した 2001 年以降, 毎年 2 〜 3 羽の幼鳥が巣立っている (中国電力 新小野田発電所 の概要 https://www.energia.co.jp/area/yamaguchi/entry/ $324 . h t m l, 2021$ 年 4 月 1 日確認)。ハヤブサは一度繁殖 を実施すると同じ場所で継続して繁殖する場合が多いこ とから, 今後も人工巣での繁殖継続が期待される.

センサーカメラによる調查は, 電源や撮影容量, 目的 以外での作動等, いくつかの問題はあるものの, 人工巣 での繁殖成功の確認は十分把握可能であり, 比較的少な い費用で簡易的に実施できる方法として有効であると考 えられる。

\section{謝 辞}

中国電力新小野田発電所には, ハヤブサ人工巣の先行 事例として, 人工巣の構造や設置状況等について重要な 情報を提供して頂いた。この場所を打借りして御礼申し 上げる。

\section{摘 要}

新仙台火力発電所（宮城県仙台市）のリプレース工事 に扔ける環境影響評価の結果を受けて，旧煙突に営巣す る小型猛禽類ハヤブサへの環境保全措置として新煙突に 人工巣を設置した。設置した人工巣の大きさは横幅 $80 \mathrm{~cm} \times$ 奥行 $55 \mathrm{~cm} \times$ 高さ $50 \mathrm{~cm}$, 設置位置は旧煙突の営 巣時の高さを参考に $76 \mathrm{~m}$ とした。 2015 年 10 月に人工 巣を設置したところ, 2016 年 8 月から利用が確認され, その後は 2017 年, 2018 年, 2020 年及び 2021 年と 4 回 繁殖し, そのうち 2017 年, 2020 年及び 2021 年の 3 回 成功した，このことは，人工巣設置が八ヤブサの保全措 置として有効であることを示していると考えられた

人工巣の利用状況はセンサーカメラを用いて観察を実 施した。 センサーカメラによって得られた情報として, 人工巣への渡来日 (時刻), 交尾, 成鳥による巣内育雛 行動 (抱卵, 抱雛, 給嘅), 餌の搬入 (回数, 時間), 卵 数, 雛数, 巣立ち日等が挙げられた。 しかし, 人工巣か ら約 $6 \mathrm{~m}$ 離れた場所からの広角撮影で人工巣内部に撮 影死角が存在したため, 卵が確認できない場合もあった ほか, 運ばれた慨の判別, 産卵の開始日や間隔, 孵化日 等の把握は困難であった。

センサーカメラによる調查は, 電源や撮影容量, 目的 以外での作動等, いくつかの問題はあるものの, ハヤブ サ人工巣での繁殖成功の確認は十分把握可能であり, 比 較的少ない費用で簡易的に実施できる方法として有効で あると考えられる。

\section{引用文献}

長谷川啓一・上野裕介 · 大城温・井上隆司（2016）道路事業 に扔ける希少猛禽類に対する効果的な人工代替巣の設置手 法と利用促進手法の検討：全国 173 事例の分析から。応用 生態工学 19(1): 67-78.

環境省（2006）レッドリスト 2006 鳥類，ぎょうせい，東京. 環境省（2014）日本の絶滅の抢それのある野生生物 $2014-$ レッドデータブックー2 鳥類. ぎょうせい, 東京.

環境省（2020）レッドリスト 2020 鳥類. ぎょうせい, 東京. 嘉藤慎譲・平井克亥・柳川久 (2021) センサーカメラを用い た猛禽類の調查一繁殖モニタリング㧍よび巣内の状況一. 第 20 回「野生生物と交通」研究発表会 論文集. 53-60.

蓑輪保男 ·岩見淳一郎 · 大桃直人 (2017) 鷹ノ巣道路事業に 扮ける環境保全対策について. 平成 29 年度 北陸地方整備 局 事業研究発表会 講演要旨. (https://www.hrr.mlit.go.jp/ library/happyoukai/h29/c/C-04.pdf, 2021 年 4 月 1 日確認)

宮城県（2001）宮城県の希少な野生動植物種一宮城県レッド データブック一. 宮城県, 宮城県.

宮城県（2016）宮城県の希少な野生動植物種一宮城県レッド データブックー. 宮城県, 宮城県. 
宮城県（2021）宮城県レッドリスト 2021 鳥類. 宮城県, 宮 城県.

森岡照明 - 叶内拓哉 ·川田隆 - 山形則男（1998）図鑑日本の ワシタカ類. 文一総合出版, 東京.

西山公夫 ·岩槻克生 ·工藤晃央（2013）道路防災事業と希少 猛禽類の共存を目指して一一般国道 336 号黄金道路におけ るハヤブサの保全について一。第 57 回（平成 25 年度）北 海道開発技術研究発表会 講演要旨.（https://thesis.ceri.go. $\mathrm{jp} / \mathrm{db} /$ files/5263989565460286286c4a.pdf, 2021 年 4 月 1 日 確認)

上野裕介 - 栗原正夫 · 大城温 - 井上隆司 - 瀧本真理 - 光谷友 樹・長谷川啓一（2016）道路環境影響評価の技術手法「13. 動物, 植物, 生態系」における環境保全のための取り組み に関する事例集 (平成 27 年度版)。国土技術政策総合研究 所資料 No. 906. 国土技術政策総合研究所. 